\title{
Rural Student Analysis : Correlation Science Process Skills and Critical Thinking at a State Senior High School in Jambi Province
}

Received: 13-06-2021; Revised: 22-12-2021; Accepted: 24-12-2021

\section{Darmaji}

Jambi University, Jambi, Indonesia

E-mail:darmaji@unja.ac.id

\section{Astalini}

Jambi University, Jambi, Indonesia

E-mail:astalinizakir@unja.ac.id

\section{Dwi Agus Kurniawan *)}

Jambi University, Jambi, Indonesia

E-mail:dwiagus.k@unja.ac.id

\section{Wita Ardina Putri}

Jambi University, Jambi, Indonesia e-mail :witaardinaputri09@gmail.com

\begin{abstract}
Science process skills and critical thinking skills are skills and abilities that must be possessed by students. So the purpose of this study is to determine the science process skills and students' critical thinking skills in the physics learning process in terms of female gender and male gender. In addition, the purpose of this study is to see how the differences and the relationship between science process skills and students' critical thinking skills are. This type of research is quantitative research with an experimental research design. The population of this study itself is the students of SMAN 6 Batanghari with a total sample of 101 people from class XII IPA1, XII IPA 2 and XII IPA 3. The sample selection technique used is total sampling technique. The instruments used in this study were observation sheets and critical thinking test instruments and interest questionnaire. The data analysis technique used is descriptive statistics and inferential statistics, Correlation hypothesis testing. The results of this study are both science process skills and students' critical thinking skills are in the good category. However, the dominant gender is women who are in the good category with a percentage of $57.6 \%$ and men in the good category with a percentage of $51.9 \%$. Meanwhile, for students' critical thinking skills, women were in a good category with a percentage of 59.8 and men in a good category with a percentage of 47.3. There are differences in science process skills and critical thinking skills between men and women. And there is a relationship of 0.357 between science process skills and students' critical thinking skills.
\end{abstract}

Abstrak: Keterampilan proses sains dan keterampilan berpikir kritis merupakan keterampilan dan kemampuan yang harus dimiliki oleh siswa. Maka tujuan dari penelitian ini adalah untuk mengetahui keterampilan proses sains dan keterampilan berpikir kritis siswa dalam proses pembelajaran fisika ditinjau dari jenis kelamin perempuan dan jenis kelamin laki-laki. Selain itu, tujuan dari penelitian ini adalah untuk melihat bagaimana perbedaan dan hubungan antara keterampilan proses sains dengan keterampilan berpikir kritis siswa. Jenis penelitian ini adalah penelitian kuantitatif dengan desain penelitian eksperimen. Populasi dari penelitian ini sendiri adalah siswa SMAN 6 Batanghari dengan jumlah sampel 101 orang dari kelas XII IPA1, XII IPA 2 dan XII IPA 3. Teknik pemilihan sampel yang digunakan adalah total sampling. Instrumen yang digunakan dalam penelitian ini adalah lembar observasi dan instrumen tes 
berpikir kritis dan angket minat belajar. Teknik analisis data yang digunakan adalah statistik deskriptif dan statistik inferensial, pengujian hipotesis korelasi. Hasil penelitian ini keterampilan proses sains dan keterampilan berpikir kritis siswa berada pada kategori baik. Namun jenis kelamin yang dominan adalah perempuan yang berada pada kategori baik dengan persentase $57,6 \%$ dan laki-laki dalam kategori baik dengan persentase 51,9\%. Sedangkan untuk kemampuan berpikir kritis siswa, perempuan berada pada kategori baik dengan persentase 59,8 dan laki-laki dalam kategori baik dengan persentase 47,3. Ada perbedaan keterampilan proses sains dan keterampilan berpikir kritis antara pria dan wanita. Dan terdapat hubungan sebesar 0,357 antara keterampilan proses sains dengan keterampilan berpikir kritis siswa.

Keywords: Science Process Skills, Critical Thinking, Correlations, Gender, Interest

\section{INTRODUCTION}

$\mathrm{E}$ ducation is a conscious effort taken by every individual to improve and develop the quality of human resources (Astiti et al., 2017; Made et al., 2017). Quality human resources can advance a country and ensure the sustainability of individual lives(Ardana \& Putra, 2017; Asrial et al., 2020). Therefore, education becomes a very important thing to be taken by every individual.

One of the sciences learned through education is physics. Physics is a science that can explain natural phenomena and interactions that occur in nature through observation(Maiyena \& Haris, 2017; Setia et al., 2017; Taqwa et al., 2019). In addition, physics is also a science that must be mastered by students in the 21st century(Karelina \& Etkina, 2007; Rokhmah et al., 2017). In studying physics, it takes a thinking ability to be able to analyze the problems that occur. The thinking ability that must be mastered by students in studying physics is the ability to think critically(Haniah et al., 2020; Sholihah \& Lastariwati, 2020).

Critical thinking ability is an ability that consists of non-cognitive and cognitive abilities which are defined as intellectual discipline processes that are carried out actively and skillfully in conceptualizing, applying, analyzing, and evaluating logical statements made in making decisions. (McPeck, 1990; Halpern, 2003; Watson \& Glaser, 2008; Canziani \& Tullar, 2017; Shaw et al., 2019). Critical thinking ability is also defined as the ability to be able to analyze an argument so that a good argument or a bad argument is obtained(Facione, 2000; Giancarlo \& Facione., 2001; Pithers \& Soden, 2000). However, the reality in the field is that the critical thinking skills possessed by students are still relatively low. This is because students still do not believe in themselves in expressing their opinions about a problem(Denny et al., 2020; Malik et al., 2017). Thus, it is necessary to improve critical thinking skills in the learning process.

One alternative that can be used to improve critical thinking skills is practicumbased learning. Besides being able to improve critical thinking skills, practicum can also improve science process skills. Science process skills are also skills that are mastered by students in the 2013 curriculum, especially in facing the 21 st century. Science process skills are skills that refer to understanding cognitive aspects(Ambross et al., 2014). Science process skills can encourage students to be able to develop the knowledge they get(Darmaji et al., 2018). Science process skills consist of two parts, namely basic science process skills and integrated science process skills. Basic science process skills consist of indicators of observing, classifying, measuring, predicting and concluding. Meanwhile, integrated science process skills consist of indicators, identifying variables, creating tables, making graphs, identifying relationships, between variables, data collection and processing, research analysis, hy- 
pothesis formation, operationally identifying variables, designing experiments, and conducting experiments.(Florencia et al., 2014; Mokiwa, 2014; Durmaz \& Mutlu, 2016; Wallace \& Coffey, 2019; Mutlu, 2020). Therefore, science process skills are very important skills to be mastered because they can grow students' thinking broadly, cognitively, critically, and can solve a problem.

Besides being able to improve critical thinking skills and science process skills, practicum activities can also foster student interest in learning. Interest is a feeling of liking and feeling of interest in something without any encouragement in it(Pasaribu, 2017). Interest plays a role in learning activities, this is because interest can encourage students to learn and produce good achievements(Hude \& Rohmah, 2017). The indicators that show that someone has an interest are showing feelings of pleasure, paying attention, having high awareness, and having high curiosity. For this reason, practicum activities are an alternative that can be used to increase interest in learning, critical thinking skills and science process skills.

Based on the description above, it is known that there is a relationship between the variables of critical thinking ability and science process skills. This is because to grow students' critical thinking skills, it is necessary to have a learning process that can maximize students' thinking processes in finding physics concepts. One way is to improve students' science process skills(Nasution, 2018). This is supported by research by(Haryono, 2006) which explains that learning centered on science process skills is a skill that can improve and encourage students to have critical thinking skills(Haryono, 2006; Nasution, 2018). So that there is a need for practicum-based learning in order to improve science process skills and students' thinking skills.

The questions to be answered in this research are:

1. How are students' science process skills in terms of gender?

2. How are students' critical thinking skills in terms of gender?
3. Is there a relationship and difference between science process skills and critical thinking skills in terms of gender?

4. How is the student's interest in learning physics?

\section{METHOD}

This research is a type of quantitative research with a correlational research design. Quantitative research is research that produces data in the form of numbers that can be generalized in the form of an overview of the observed phenomena(Creswell, 2014).

The population is all research objects that are analyzed and concluded to be used as research samples (Arisantiani et al., 2017; Astiti et al., 2017). The population used in this study were all students of class XII IPA at SMAN 6 Batanghari with a total of 101 students. The sample used in this study is the same as the total population, namely all students of class XII IPA with a total of 101 students. so that the sampling technique used in this study is total sampling.

The instruments or measuring instruments used in this study were in the form of observation sheets for science process skills, critical thinking ability test instruments, and a learning interest questionnaire. The observation sheet is used to find out or observe the activities of students when doing practicum(Astuti \& Mustadi, 2014; Israel et al., 2016; Rahmawati \& Mahmudi, 2014). While the critical thinking ability essay test instrument is used to determine student learning outcomes after doing practicum(Ayuni et al., 2017; Handika \& Wangid, 2013; Istiyono, 2020). The test instrument used consisted of five essay questions with direct current material. The test instrument is given to students after students do practicum. For student learning interest questionnaires are used to see how students' interest in learning physics.

The data collection technique was carried out by students doing practicum and then observers assessing students' science process skills by using scientific process skills observation instruments. After completing the practicum, the next step the researcher gave a critical thinking test question and contin- 
ued by distributing student interest questionnaires. so that the data obtained in this study were derived from the instrument of observation sheets, tests of critical thinking skills and questionnaires of interest in learning.

The data analysis techniques used in this research are descriptive statistics and inferential statistics. Descriptive analysis technique is used to describe a variable under study(Anindyta \& Suwarjo, 2014; Quinteladel-río \& Francisco-fernández, 2016; Wyatt et al., 2017). The statistics used are the mean, median, maximum and minimum values(Mariana \& Zubaida, 2015; Marquezin et al., 2016). For inferential statistical analysis, correlational test and ANOVA. test were used(Arisantiani et al., 2017; Darmaji et al., 2020). Before conducting the inferential test, the first step of the researcher conducted a prerequisite test in the form of a normality test and a homogeneity test and then continued with a correlation test and ANOVA test.

The research design conducted by the researcher is as follows:

Figure 1. Research

Flowchart

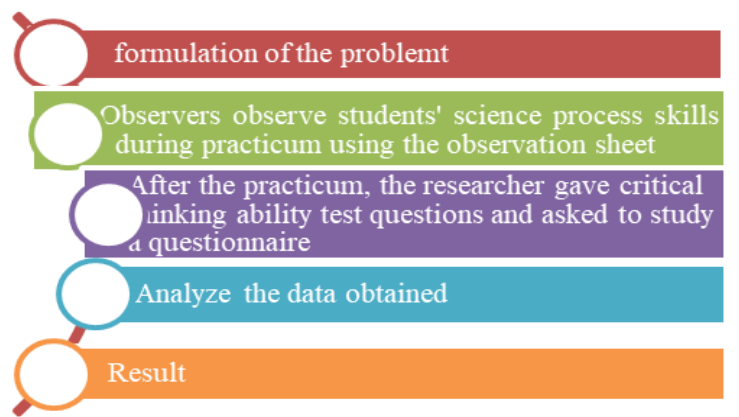

The intervals and categories of science process skills, critical thinking skills, and student interest in learning are as follows.

Table 1. Categories of Science Process Skills

\begin{tabular}{|c|c|c|}
\hline \multicolumn{3}{|c|}{ Science Process Skills } \\
\hline Indicator & Hose & Category \\
\hline \multirow[t]{4}{*}{ Observe } & $6.00-10.50$ & Not so good \\
\hline & $10.51-1.00$ & Not good \\
\hline & $15.01-19.50$ & Good \\
\hline & $19.51-24.00$ & Very well \\
\hline \multirow{4}{*}{ Measuring } & $5.00-8.75$ & Not so good \\
\hline & $8.76-12.50$ & Not good \\
\hline & $12.51-16.25$ & Good \\
\hline & $16.26-20.00$ & Very well \\
\hline \multirow{4}{*}{ Conclude } & $4.00-7.00$ & Not so good \\
\hline & $7.01-10.00$ & Not good \\
\hline & $10.01-13.00$ & Good \\
\hline & $13.01-16.00$ & Very well \\
\hline \multirow{4}{*}{$\begin{array}{l}\text { Designing } \\
\text { experiments }\end{array}$} & $6.00-10.50$ & Not so good \\
\hline & $10.51-15.00$ & Not good \\
\hline & $15.01-19.50$ & Good \\
\hline & $19.51-24.00$ & Very well \\
\hline \multirow{4}{*}{ Test } & $12.00-21.00$ & Not so good \\
\hline & $21.01-30.00$ & Not good \\
\hline & $30.01-39.00$ & Good \\
\hline & $39.01-48.00$ & Very well \\
\hline \multirow{4}{*}{$\begin{array}{l}\text { Create a } \\
\text { table }\end{array}$} & $3.00-5.25$ & Not so good \\
\hline & $5.26-7.50$ & Not good \\
\hline & $7.51-9.75$ & Good \\
\hline & $9.76-12.00$ & Very well \\
\hline
\end{tabular}

Table.2 Categories of Critical Thinking

\begin{tabular}{ll}
\hline \multicolumn{2}{c}{ Critical thinking } \\
\hline Hose & Category \\
\hline $0.00-5.00$ & Not so good
\end{tabular}


5.50-10.00 Not good

10.50-15.00 Good

$15.50-20.00$ Very well

Table 3. Categories of Learning Interest

\begin{tabular}{cl}
\hline interval & \multicolumn{1}{c}{ Category } \\
\hline $16.0-28.0$ & Not very good \\
$28.1-40.0$ & Not good \\
$40.1-52.0$ & Good \\
$52.1-64.0$ & Very good \\
\hline
\end{tabular}

\section{RESULTS AND DISCUSSION}

Research on science process skills has been carried out by Darmaji, et al (2018) with the observed indicators including observation, classification, making hypotheses, relationships between variables, planning experiments, measuring, obtaining and processing data, experimental analysis, communication, and conclusions with results. research shows that there are still many students who have not mastered science process skills. While research on critical thinking skills has also been carried out by Nuryanti, et.al (2018) with research results showing that students' critical thinking skills are still low. For this reason, this study complements previous research, namely reviewing the re- lationship between science process skills and critical thinking skills and analyzing student learning interests. The following is a description of the science process skills of class XII IPA 1 students,

1. Science Process Skills for Class XII IPA 1, XII IPA 2, XII IPA 3 in terms of gender differences

Science process skills are one of the skills that must be mastered and possessed by students in accordance with the 2013 curriculum. The science process skills studied in this study include indicators of observing, measuring, concluding, designing experiments, and making tables.

Table 4. is a description of science process skills on observing indicators

\begin{tabular}{|c|c|c|c|c|c|c|}
\hline \multicolumn{5}{|c|}{ IPA class 1} & \multirow[b]{2}{*}{ mean } & \multirow[b]{2}{*}{ median } \\
\hline Gender & Hose & $\mathrm{F}$ & $\%$ & Category & & \\
\hline \multirow{5}{*}{ Woman } & $6.00-10.50$ & 0 & 0 & Not so good & 15.47 & 16.00 \\
\hline & $10.51-1.00$ & 8 & 47.1 & Not good & & \\
\hline & $15.01-19.50$ & 9 & 52.9 & Good & & \\
\hline & $19.51-24.00$ & 0 & 0 & Very well & & \\
\hline & $6.00-10.50$ & 0 & 0 & Not so good & 17.07 & 18.00 \\
\hline \multirow{3}{*}{ Man } & $10.51-1.00$ & 3 & 21.4 & Not good & & \\
\hline & $15.01-19.50$ & 8 & 57.1 & Good & & \\
\hline & $19.51-24.00$ & 3 & 21.4 & Very well & & \\
\hline \multicolumn{5}{|c|}{ Science Class 2} & & \\
\hline Gender & Hose & $\mathrm{F}$ & $\%$ & Category & & \\
\hline \multirow{3}{*}{ Woman } & $6.00-10.50$ & 1 & 0.3 & Not so good & 18.31 & 18.00 \\
\hline & $10.51-1.00$ & 3 & 18.8 & Not good & & \\
\hline & $15.01-19.50$ & 9 & 56.3 & Good & & \\
\hline \multirow{5}{*}{ Man } & $19.51-24.00$ & 3 & 18.8 & Very well & & \\
\hline & $6.00-10.50$ & 1 & 5.6 & Not so good & 12.94 & 13.00 \\
\hline & $10.51-1.00$ & 0 & 0 & Not good & & \\
\hline & $15.01-19.50$ & 17 & 94.4 & Good & & \\
\hline & $19.51-24.00$ & 0 & 0 & Very well & & \\
\hline \multicolumn{5}{|c|}{ IPA class 3} & & \\
\hline Gender & Hose & $\mathrm{F}$ & $\%$ & Category & & \\
\hline \multirow[b]{2}{*}{ Woman } & $6.00-10.50$ & 0 & 0 & Not so good & 16.05 & 16.00 \\
\hline & $10.51-1.00$ & 8 & 24.3 & Not good & & \\
\hline
\end{tabular}




\begin{tabular}{lllllll}
\hline & $15.01-19.50$ & 10 & 70.4 & Good & & \\
& $19.51-24.00$ & 1 & 18.8 & Very well & & \\
\hline \multirow{3}{*}{ Man } & $6.00-10.50$ & 1 & 5.9 & Not so good & 12.88 & 13.00 \\
& $10.51-1.00$ & 14 & 82.4 & Not good & & \\
& & & & & & \\
& $15.01-19.50$ & 2 & 11.8 & Good & & \\
& $19.51-24.00$ & 0 & 0 & Very well & & \\
\hline
\end{tabular}

Based on the table presented, the results of the study indicate that the indicators observed indicate that the female sex in science class 1 is in the good category with a percentage of $52.9 \%$ with an average value of 15.47 and a median of 16.00 . For science class 2, women are in the good category with a percentage of $56.3 \%$ with a mean value of 18.31 and a median of 18.00. Meanwhile, for science class 3, girls are in the good category with a percentage of $70.4 \%$ with an average value of 16.05 and a median of 16.00.

For the male gender, the IPA class 1 results were in good category with a percentage of 57.1 and a mean value of 17.07 and a median of 18.00 . In class
IPA 2, good results were obtained with the percentage of males being $94.4 \%$ with an average value of 12.94 and a median of 13.00. Meanwhile, for science class 3 the results were not good with a percentage of $82.4 \%$ and an average value of 12.88 and a median of 13.00. Based on the results obtained on the observed indicators, both female and male sex in class XII IPA 1, XII IPA 2, and XII IPA 3 are in the good category.

a. Measure

The following is presented in Table 5 which is an overview of the intervals and categories indicators of science process skills for class XII IPA 1, XII IPA 2 and XII IPA 3 in terms of gender differences.

Table 5. Description of Science Process Skills Indicator Measuring

\begin{tabular}{|c|c|c|c|c|c|c|}
\hline \multicolumn{5}{|c|}{ IPA class 1} & \multirow[t]{2}{*}{ mean } & \multirow[t]{2}{*}{ median } \\
\hline Gender & Hose & $\mathrm{F}$ & $\%$ & Category & & \\
\hline & $5.00-8.75$ & 0 & 0 & Very Not Good & 13.32 & 14.00 \\
\hline \multirow[t]{5}{*}{ Woman } & $8.76-12.50$ & 5 & 29.4 & Not good & & \\
\hline & $12.51-16.25$ & 12 & 70.6 & Good & & \\
\hline & $16.26-20.00$ & 0 & 0 & Very good & & \\
\hline & $5.00-8.75$ & 0 & 0 & Very Not Good & 13.14 & 13.00 \\
\hline & $8.76-12.50$ & 5 & 35.7 & Not good & & \\
\hline \multirow[t]{2}{*}{ Man } & $12.51-16.25$ & 9 & 64.3 & Good & & \\
\hline & $16.26-20.00$ & 0 & 0 & Very good & & \\
\hline \multicolumn{7}{|c|}{ Science Class 2} \\
\hline \multirow[t]{2}{*}{ Gender } & Hose & $\mathrm{F}$ & $\%$ & Category & & \\
\hline & $5.00-8.75$ & 1 & 6.3 & Very Not Good & 14.6 & 15.00 \\
\hline \multirow[t]{4}{*}{ Woman } & $8.76-12.50$ & 3 & 18.8 & Not good & & \\
\hline & $12.51-16.25$ & 4 & 25.0 & Good & & \\
\hline & $16.26-20.00$ & 8 & 50.0 & Very good & & \\
\hline & $5.00-8.75$ & 3 & 16.7 & Very Not Good & 11.72 & 12.00 \\
\hline \multirow[t]{3}{*}{ Man } & $8.76-12.50$ & 6 & 33.3 & Not good & & \\
\hline & $12.51-16.25$ & 9 & 50.0 & Good & & \\
\hline & $16.26-20.00$ & 0 & 0 & Very good & & \\
\hline \multicolumn{7}{|c|}{ IPA class 3} \\
\hline Gender & Hose & $\mathrm{F}$ & $\%$ & Category & & \\
\hline \multirow[t]{4}{*}{ Woman } & $5.00-8.75$ & 0 & 0 & Very Not Good & 17.00 & 17.00 \\
\hline & $8.76-12.50$ & 8 & 24.3 & Not good & & \\
\hline & $12.51-16.25$ & 10 & 70.4 & Good & & \\
\hline & $16.26-20.00$ & 1 & 18.8 & Very good & & \\
\hline Man & $5.00-8.75$ & 1 & 5.9 & Very Not Good & 12.35 & 12.00 \\
\hline
\end{tabular}




$\begin{array}{llll}8.76-12.50 & 14 & 82.4 & \text { Not good } \\ 12.51-16.25 & 2 & 11.8 & \text { Good } \\ 16.26-20.00 & 0 & 0 & \text { Very good }\end{array}$

Based on table 5, the female gender in measuring skills in science class 1 is in the good category with a percentage of $70.6 \%$ and a mean value of 13.32 and a median of 14.00. For science class 2 the skill of measuring female gender is in the very good category with a percentage of $50 \%$ with a mean value of 14.6 and a median of 15.00. In science class 3 , the female gender was in the very good category with a percentage of $68.4 \%$ and an average value of 17.00 and a median of 17.00. The male gender in science class 1 obtained good results with a percentage of $64.3 \%$ and an average value of 13.14

with a median of 13.00. For male students in science class 2 obtained a good category with a percentage of $50 \%$ and an average value of 11.72 with a median of 12.00. Meanwhile, for men in science class 3 the results were not good with a percentage of $52.9 \%$ and a mean value of 12.35 and a median of 12.00 .

b. Conclude

Furthermore, Table 6 is a table description of the category of science process skills on the concluding indicators for students of class XII IPA 1, XII IPA 2 , and XII IPA 3 in terms of gender differences

Table 6. Description of Science Process Skills Indicator Concluding

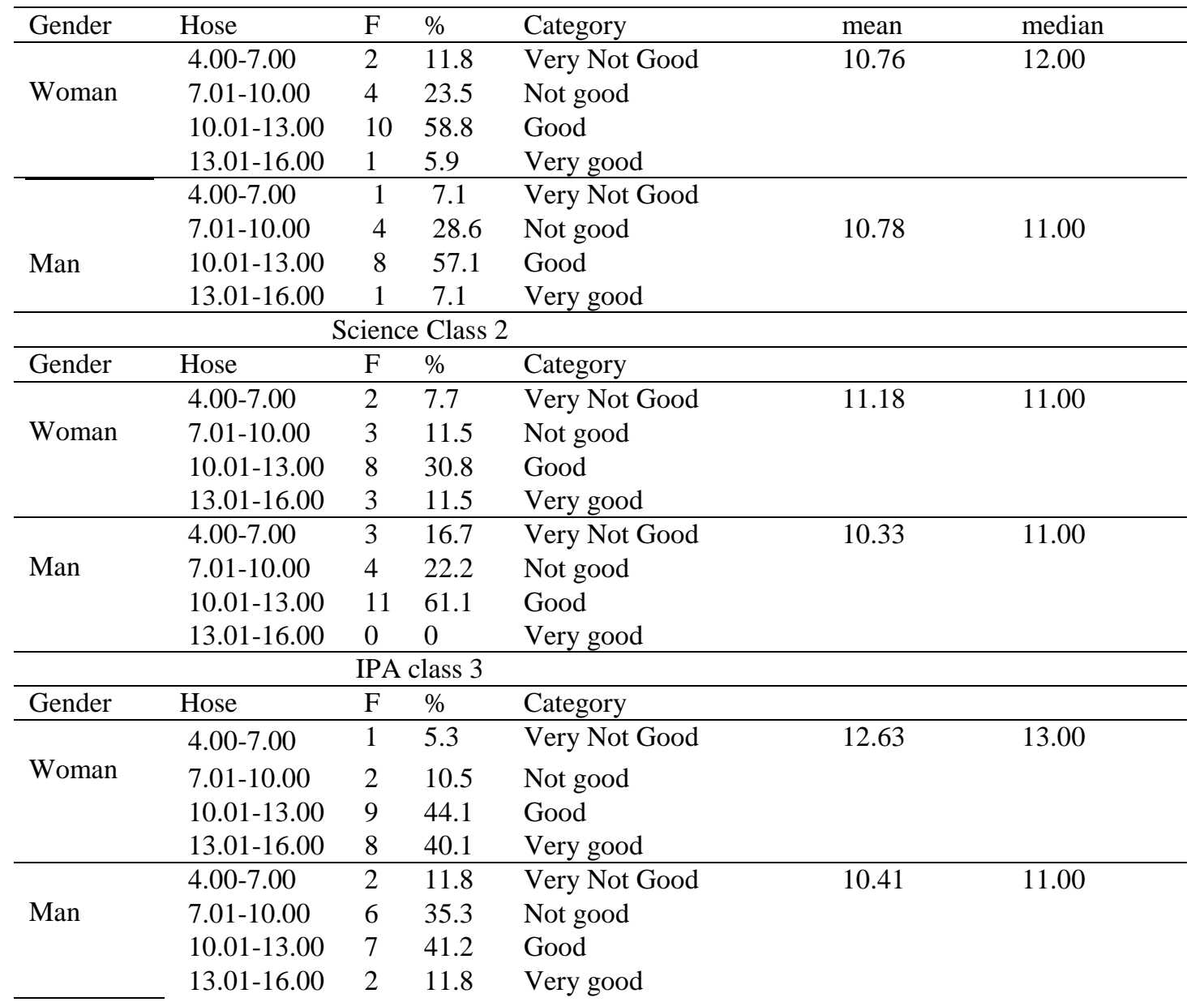

Based on table 6 , the results show that women in science class 1 have a good conclusion indicator category with a percentage of $59.8 \%$ and a mean value of 10.76 and a median of 12.00 . Meanwhile, for women in class XII 
IPA 2, the results showed that the indicators concluded that they were categorized as good with a percentage of $30.8 \%$, an average value of 11.18 and a median value of 11.00. And for class XII IPA 3 women are also in the good category with a percentage of $44.1 \%$, an average of 12.63 and a median of 13.00. The male gender in science class 1 obtained good results with a percentage of $57.1 \%$, the mean value of 10.78 and the median of 11.00 . For men in science class 2 , the good category was obtained with a percentage of $61.1 \%$, a mean value of 10.33 and a median of 11.00. Meanwhile, for men in science class 3 the results are not good with a percentage of $52.9 \%$, the mean value is 10.41 and the median is 11.00 .

c. Designing Experiments

Table 7 is a table of the results of the description of science process skills on the indicators of designing experiments for students of class XII IPA 1, XII IPA 2 and XII IPA 3 in terms of gender differences. The results are presented as follows.

Table 7. Description of Science Process Skills Indicators Designing ExperimentsIPA class 1

\begin{tabular}{|c|c|c|c|c|c|c|}
\hline Gender & Hose & $\mathrm{F}$ & $\%$ & Category & mean & median \\
\hline & $6.00-10.50$ & 1 & 5.9 & Very Not Good & 15.17 & 15.00 \\
\hline \multirow[t]{5}{*}{ Woman } & $10.51-15.00$ & 8 & 47.0 & Not good & & \\
\hline & $15.01-19.50$ & 9 & 47.1 & Good & & \\
\hline & $19.51-24.00$ & 0 & 0 & Very good & & \\
\hline & $6.00-10.50$ & 2 & 14.3 & Very Not Good & 13.50 & 14.00 \\
\hline & $10.51-15.00$ & 8 & 57.1 & Not good & & \\
\hline \multirow[t]{3}{*}{ Man } & $15.01-19.50$ & 4 & 28.6 & Good & & \\
\hline & $19.51-24.00$ & 0 & 0 & Very good & & \\
\hline & \multicolumn{4}{|c|}{ Science Class 2} & & \\
\hline Gender & Hose & $\mathrm{F}$ & $\%$ & Category & & \\
\hline \multirow{4}{*}{ Woman } & $6.00-10.50$ & 0 & 0 & Very Not Good & 16.68 & 17.50 \\
\hline & $10.51-15.00$ & 1 & 6.3 & Not good & & \\
\hline & $15.01-19.50$ & 11 & 73.1 & Good & & \\
\hline & $19.51-24.00$ & 4 & 20.6 & Very good & & \\
\hline \multirow{4}{*}{ Man } & $6.00-10.50$ & 4 & 22.2 & Very Not Good & 12.16 & 12.00 \\
\hline & $10.51-15.00$ & 10 & 55.6 & Not good & & \\
\hline & $15.01-19.50$ & 4 & 22.2 & Good & & \\
\hline & $19.51-24.00$ & 0 & 0 & Very good & & \\
\hline \multicolumn{7}{|c|}{ IPA class 3} \\
\hline Gender & Hose & $\mathrm{F}$ & $\%$ & Category & & \\
\hline \multirow{4}{*}{ Woman } & $6.00-10.50$ & 1 & 5.3 & Very Not Good & 16.26 & 16.00 \\
\hline & $10.51-15.00$ & 6 & 31.6 & Not good & & \\
\hline & $15.01-19.50$ & 10 & 52.6 & Good & & \\
\hline & $19.51-24.00$ & 2 & 10.5 & Very good & & \\
\hline \multirow{4}{*}{ Man } & $6.00-10.50$ & 6 & 35.3 & Very Not Good & 13.64 & 13.00 \\
\hline & $10.51-15.00$ & 10 & 58.8 & Not good & & \\
\hline & $15.01-19.50$ & 1 & 5.9 & Good & & \\
\hline & $19.51-24.00$ & 0 & 0 & Very good & & \\
\hline
\end{tabular}

in table 8. Based on table 8 , it is known that the data on female sex in science class 1 is in the good category with a percentage of $47.1 \%$ and a mean value of 15.17 and a median of 15.00. For women in science class 2 , the good category was obtained with the results of

$73.1 \%$ with an average value of 16.68 and a median of 17.50. Meanwhile, for female science class 3, good results were obtained with a percentage of $52.6 \%$ with a mean value of 16.26 and a median of 16.00 . 
For the male gender, the IPA class 1 results in the poor category with a percentage of $57.1 \%$ and a mean value of 13.50 and a median of 14.00. For men in science class 2 the category is not good with a percentage of $55.6 \%$ and a mean value of 12.16 and a median of 12.00 . Meanwhile for men in science class 3 the results are not good with a percentage of
$58.8 \%$ and a mean value of 13.64 and a median of 13.00 .

d. Doing Experiments

Furthermore, table 11 is presented which is a description table of the science process skills indices conducting experiments on students of class XII IPA 1, XII IPA 2, and XII IPA 3.

Table 11. Description of Science Process Skills Indicators of Conducting Experiments

\begin{tabular}{|c|c|c|c|c|c|c|}
\hline \multicolumn{7}{|c|}{ IPA Class 1} \\
\hline Gender & Interval & $\mathrm{F}$ & $\%$ & Category & mean & median \\
\hline \multirow{4}{*}{ female } & $4.00-7.00$ & 0 & 0 & Not Very Good & 11.00 & 11.00 \\
\hline & $7.01-10.00$ & 7 & 41.2 & Not Good & & \\
\hline & $10.01-13.00$ & 9 & 52.9 & Good & & \\
\hline & $13.01-16.00$ & 1 & 5.9 & Very Good & & \\
\hline \multirow{4}{*}{ Male } & $4.00-7.00$ & 2 & 14.3 & Not Very Good & 9.64 & 10.00 \\
\hline & $7.01-10.00$ & 4 & 28.6 & Not Good & & \\
\hline & $10.01-13.00$ & 8 & 57.1 & good & & \\
\hline & $13.01-16.00$ & 0 & 0 & Very Good & & \\
\hline \multicolumn{7}{|c|}{ IPA Class 2} \\
\hline Gender & Interval & $\mathrm{F}$ & $\%$ & Category & & \\
\hline \multirow{4}{*}{ female } & $4.00-7.00$ & 3 & 15.8 & Not Very Good & 11.68 & 13.00 \\
\hline & $7.01-10.00$ & 2 & 10.5 & Not Good & & \\
\hline & $10.01-13.00$ & 10 & 52.6 & Good & & \\
\hline & $13.01-16.00$ & 4 & 21.1 & Very Good & & \\
\hline \multirow{4}{*}{ Male } & $4.00-7.00$ & 2 & 11.1 & Not Very Good & 9.55 & 10.00 \\
\hline & $7.01-10.00$ & 11 & 61.1 & Not Good & & \\
\hline & $10.01-13.00$ & 3 & 16.7 & good & & \\
\hline & $13.01-16.00$ & 2 & 11.1 & Very Good & & \\
\hline \multicolumn{7}{|c|}{ IPA Class 3} \\
\hline Gender & Interval & $\mathrm{F}$ & $\%$ & Category & & \\
\hline \multirow{4}{*}{ female } & $4.00-7.00$ & 1 & 5.3 & Not Very Good & 11.21 & 11.00 \\
\hline & $7.01-10.00$ & 5 & 26.3 & Not Good & & \\
\hline & $10.01-13.00$ & 12 & 63.2 & Good & & \\
\hline & $13.01-16.00$ & 1 & 5.3 & Very Good & & \\
\hline \multirow{4}{*}{ Male } & $4.00-7.00$ & 3 & 17.6 & Not Very Good & 9.29 & 9.00 \\
\hline & $7.01-10.00$ & 11 & 64.7 & Not Good & & \\
\hline & $10.01-13.00$ & 2 & 11.8 & Good & & \\
\hline & $13.01-16.00$ & 1 & 5.9 & Very Good & & \\
\hline
\end{tabular}

Based on table 11 results of class students IPA 1 female is in the good category with a percentage of $52.9 \%$ with a mean value of 11.00 and a median of 11.00. IPA class 2 female students get the results; which is good with a percentage of $52.6 \%$ and an average value of 11.68 and a median of 13.00. While the IPA 3 women are also included in the good category with a percentage of $63.2 \%$ with an average value of 11.21 and a median of 11.00 . Male science class 1 is in the good category with a percentage of $57.1 \%$ and a mean of 9.64 and a median of 10.00 . For men in science class 2 the results were not good with a percentage of $61.1 \%$ with an average value of 9.55 and a median of 10.00. Meanwhile, for IPA class 3 the results are not good with $\mathrm{p}$ percentage $64.7 \%$ and mean 9.29 and median 9.00 
e. Creating Tables

Table 12 is a table of categories of indicators for science process skills in making experimental tables for students of class XII IPA 1, XII IPA 2, and XII IPA 3 in terms of gender.

Table 12. Description of Science Process Skills Indicator Making Table

\begin{tabular}{|c|c|c|c|c|c|c|}
\hline \multirow[b]{2}{*}{ Gender } & \multicolumn{4}{|c|}{ IPA Class 1} & \multirow{3}{*}{$\begin{array}{l}\text { mean } \\
11.58\end{array}$} & \multirow{3}{*}{$\begin{array}{l}\text { median } \\
11.00\end{array}$} \\
\hline & interval & $\mathrm{F}$ & $\%$ & Category & & \\
\hline & $4.00-7.00$ & 0 & 0 & Not Very Good & & \\
\hline \multirow[t]{5}{*}{ female } & $7.01-10.00$ & 3 & 17.6 & Not Good & & \\
\hline & $10.01-13.00$ & 12 & 70.6 & good & & \\
\hline & $13.01-16.00$ & 2 & 11.8 & Very Good & & \\
\hline & $4.00-7.00$ & 4 & 28.6 & Not Very Good & 9.64 & 10.50 \\
\hline & $7.01-10.00$ & 3 & 21.4 & Not Good & & \\
\hline \multirow[t]{2}{*}{ Male } & $10.01-13.00$ & 7 & 50.0 & good & & \\
\hline & $13.01-16.00$ & 0 & 0 & Very Good & & \\
\hline \multicolumn{7}{|c|}{ Science Class 2} \\
\hline Gender & interval & $\mathrm{F}$ & $\%$ & Category & & \\
\hline \multirow{4}{*}{ female } & $4.00-7.00$ & 2 & 10.5 & Not Very Good & 11.43 & 12.00 \\
\hline & 7.01-10.00 & 2 & 10.5 & Not Good & & \\
\hline & $10.01-13.00$ & 12 & 63.2 & good & & \\
\hline & $13.01-16.00$ & 3 & 15.8 & Very Good & & \\
\hline \multirow{4}{*}{ Male } & $4.00-7.00$ & 3 & 16.7 & Not Very Good & 9.72 & 10.50 \\
\hline & 7.01-10.00 & 6 & 33.3 & Not Good & & \\
\hline & $10.01-13.00$ & 9 & 50.0 & good & & \\
\hline & $13.01-16.00$ & 0 & 0 & Very Good & & \\
\hline \multicolumn{7}{|c|}{ IPA class 3} \\
\hline Gender & interval & $\mathrm{F}$ & $\%$ & Category & & \\
\hline \multirow{4}{*}{ female } & $4.00-7.00$ & 1 & 5.3 & Not Very Good & 11.68 & 11.00 \\
\hline & 7.01-10.00 & 3 & 15.8 & Not Good & & \\
\hline & $10.01-13.00$ & 11 & 57.9 & good & & \\
\hline & $13.01-16.00$ & 4 & 21.1 & Very Good & & \\
\hline \multirow{4}{*}{ Male } & $4.00-7.00$ & 2 & 11.8 & Not Very Good & 9.88 & 10.00 \\
\hline & $7.01-10.00$ & 6 & 35.3 & Not Good & & \\
\hline & $10.01-13.00$ & 7 & 41.2 & good & & \\
\hline & $13.01-16.00$ & 2 & 11.8 & Very Good & & \\
\hline
\end{tabular}

Based on table 12 , the results of the female science class 1 students are in the good category with a percentage of $70.6 \%$ with a mean value of 11.58 and a median of 11.00. The female students of science class 2 got good results with a percentage of $63.2 \%$ and a mean value of 11.43 with a median of 12.00. Meanwhile, women in science class 3 are also in the good category with a percentage of $57.9 \%$ with a mean value of 11.68 and a median of 11.00 .

Boys in science class 1 are in the good category with a percentage of $50 \%$ and an average of 9.64 and a median of 10.50 . For men in science class 2 the results are not good with a percentage of $50 \%$ with an average value of 9.72 with a median of 10.50 .

Meanwhile, for science class 3, good results were also obtained with a percentage of $41.2 \%$ and a mean value of 9.88 and a median of 10.00 .

After describing students' science process skills in terms of gender differences, the researchers then described students' critical thinking skills in terms of gender differences.

2. Description of Critical Thinking Ability of Class XII IPA 1, XII IPA 2, and XII IPA 3 students, in terms of gender differences

Critical thinking ability is an ability that must be possessed by students. Critical thinking ability is the ability to 
be able to analyze problems and provide solutions to problems. The following table 13 is a description of the critical thinking skills of students in class XII
IPA 1, XII IPA 2, and XII IPA 3 in terms of gender differences.

Table 13. Description of Critical Thinking Ability of Class XII IPA 1, XII IPA 2 and XII IPA 3 students in terms of gender differences

\begin{tabular}{|c|c|c|c|c|c|c|}
\hline \multicolumn{7}{|c|}{ IPA Class 1} \\
\hline Gender & interval & $\mathrm{F}$ & $\%$ & Category & mean & median \\
\hline \multirow{4}{*}{ female } & $0.0-5.0$ & 0 & 0 & Not Very Good & 14.82 & 15.00 \\
\hline & $5.5-10.0$ & 0 & 0 & Not Good & & \\
\hline & $10.5-15.0$ & 12 & 70.6 & good & & \\
\hline & $15.5-20.0$ & 5 & 29.4 & Very Good & & \\
\hline \multirow{4}{*}{ Male } & $0.0-5.0$ & 0 & 0 & Not Very Good & 11.78 & 12.00 \\
\hline & $5.5-10.0$ & 2 & 14.3 & Not Good & & \\
\hline & $10.5-15.0$ & 12 & 85.7 & good & & \\
\hline & $15.5-20.0$ & 0 & 0 & Very Good & & \\
\hline \multicolumn{7}{|c|}{ IPA Class 2} \\
\hline Gender & interval & $\mathrm{F}$ & $\%$ & Category & & \\
\hline \multirow{4}{*}{ female } & $0.0-5.0$ & 0 & 0 & Not Very Good & 13.12 & 13.59 \\
\hline & $5.5-10.0$ & 3 & 18.8 & Not Good & & \\
\hline & $10.5-15.0$ & 9 & 56.3 & good & & \\
\hline & $15.5-20.0$ & 4 & 25.0 & Very Good & & \\
\hline \multirow{4}{*}{ Male } & $0.0-5.0$ & 0 & 0 & Not Very Good & 10.33 & 10.50 \\
\hline & $5.5-10.0$ & 8 & 43.7 & Not Good & & \\
\hline & $10.5-15.0$ & 9 & 56.3 & good & & \\
\hline & $15.5-20.0$ & 0 & 0 & Very Good & & \\
\hline \multicolumn{7}{|c|}{ IPA Class 3} \\
\hline Gender & interval & $\mathrm{F}$ & $\%$ & Category & & \\
\hline \multirow{4}{*}{ female } & $0.0-5.0$ & 0 & 0 & Not Very Good & 11.00 & 11.00 \\
\hline & $5.5-10.0$ & 8 & 42.1 & Not Good & & \\
\hline & $10.5-15.0$ & 10 & 52.6 & good & & \\
\hline & $15.5-20.0$ & 1 & 5.3 & Very Good & & \\
\hline \multirow{4}{*}{ Male } & $0.0-5.0$ & 0 & 0 & Not Very Good & 9.11 & 9.00 \\
\hline & $5.5-10.0$ & 15 & 88.2 & Not Good & & \\
\hline & $10.5-15.0$ & 2 & 11.8 & good & & \\
\hline & $15.5-20.0$ & 0 & 0 & Very Good & & \\
\hline
\end{tabular}

Table 13 is a description table of students' critical thinking skills in class XII IPA 1, XII IPA 2, XII IPA 3. Based on the table, it is known that in class science 1 , the female gender is in the good category with a percentage of $70.6 \%$ and a mean value of 14.82 , median 15.00. For female gender, science class 2 is in the good category with a percentage of $56.3 \%$ and a mean value of 13.12 , median of 13.50 . The gender of women in science class 3 is also included in the good category with a percentage of $52.6 \%$ and a mean of 11.00 , median of 11.00 .
The male gender in science class 1 is in the good category with a percentage of $85.7 \%$ and a mean value of 11.78 , median of 12.00. Science class 2 is in the good category with a percentage of $56.3 \%$ and a mean value of 10.33, median of 10.50 . While the science class 3 is in the bad category with a percentage of $88.2 \%$ and an average value of 9.11, median 9.00 .

3. Relationship between Science Process Skills and Critical Thinking Ability

To see the relationship between science process skills and students' critical thinking skills, the researchers used inferential statistics here. Inferential 
statistics are divided into prerequisite tests and hypothesis testing. The prerequisite test used is the normality test and homogeneity test. While the hypothesis test used is a correlation test. In the following, the results of the inferential statistics of the normality test of data on science process skills and students' critical thinking skills are presented.

Table 14. SPS \& CT . Normality Test

\begin{tabular}{lrrrr}
\hline Indicator & class & $\begin{array}{c}\text { Shapiro-Wilk } \\
\text { Statistics }\end{array}$ & df & Sig. \\
\hline SPS & IPA 1 & .945 & 31 & .381 \\
& IPA 2 & .969 & 34 & .817 \\
& IPA 3 & .954 & 36 & .434 \\
\hline CT & IPA 1 & .181 & 31 & .200 \\
& IPA 2 & .186 & 34 & .098 \\
& IPA 3 & .201 & 36 & 068 \\
\hline
\end{tabular}

Based on table 14, it is known that the normality test of students' science process skills in science class 1 is 0.381 , in science class 2 is 0.817 and in science class 3 is 0.434 . Meanwhile, for the ability to think critically, the IPA 1 class is 0.200 , the IPA 2 class is 0.098 and the IPA 3 class is 0.068 .

Based on these results, the data can be said to be normal because the significance value obtained is greater than 0.05 .
After conducting the normality test, the prerequisite that must be met is that the data must be homogeneous. To find out whether the data is homogeneous or not, the researchers conducted a homogeneity test. The following table 15 is a test of the homogeneity of science process skills and critical thinking skills of class XII science students.

Table 15. SPS \& CT Homo Homogeneity Test

\begin{tabular}{llccc}
\hline Gender & $\begin{array}{l}\text { Levena } \\
\text { Statistics }\end{array}$ & df1 & df2 & Sig. \\
\hline SPS & 2,670 & 2 & 99 & .079 \\
CT & .441 & 2 & 99 & .646 \\
\hline
\end{tabular}

Based on table 15 presented, it is known that the SPS \& CT data are homogeneous. This can be seen from the significance value of SPS \& CT. For SPS the score is 0.079 and CT is 0.646 . From these results it can be seen that the significance value is greater than 0.05 , so the data can be said to be homogeneous.

Then, to answer the research objectives, the researchers tested the hypothesis, namely the correlation test. Correlation test is an inferential statistic that is used to determine the relationship between variables. The following table presents the correlation test for SPS \& CT variables.

Table 16. Correlation Test

\begin{tabular}{llll}
\hline \multicolumn{4}{c}{ Correlations } \\
& \multicolumn{1}{c}{ KPS } & CT \\
\hline \multirow{3}{*}{ SPS } & Pearson Correlation & 1 & $.657^{* *}$ \\
& Sig. (2-tailed) & & .000 \\
& N & 101 & 101 \\
& Pearson Correlation & $.657 * *$ & 1 \\
CT $\quad$ Sig. (2-tailed) & .000 & \\
& N & 101 & 101 \\
$* *$ * Correlation is significant at the 0.01 level (2-tailed).
\end{tabular}

Based on table 16 that has been presented, it is known that there is a relationship between science process skills and students' critical thinking skills. This can be seen from the significance value obtained between science process skills and critical thinking skills which is
0.000 less than 0.05. Meanwhile, if viewed from the Pearson correlation value, it is known that the relationship between science process skills and critical thinking skills is a strong relationship. This is because it can be seen that the Pearson correlation value is 
0.657. Furthermore, to answer the third goal, namely knowing students' interest in learning, the researchers conducted a description test to see students' interest in learning in their eyes physics. The description test of learning interest is presented in table 17.

Table 17. Description of Student Interests

\begin{tabular}{|c|c|c|c|c|c|c|}
\hline \multirow[b]{2}{*}{ Gender } & \multicolumn{4}{|c|}{ IPA Class 1} & \multirow{3}{*}{$\begin{array}{l}\text { mean } \\
53.23\end{array}$} & \multirow{3}{*}{$\begin{array}{l}\text { median } \\
53.00\end{array}$} \\
\hline & interval & $\mathrm{F}$ & $\%$ & Category & & \\
\hline & $16.0-28.0$ & 0 & 0.0 & Not Very Good & & \\
\hline \multirow[t]{5}{*}{ female } & $28.1-40.0$ & 0 & 0.0 & Not Good & & \\
\hline & $40.1-52.0$ & 7 & 41.2 & good & & \\
\hline & $52.1-64.0$ & 10 & 58.8 & Very Good & & \\
\hline & $16.0-28.0$ & 4 & 28.6 & Not Very Good & 50.42 & 49.50 \\
\hline & $28.1-40.0$ & 3 & 21.4 & Not Good & & \\
\hline \multirow[t]{2}{*}{ Male } & $40.1-52.0$ & 7 & 50.0 & good & & \\
\hline & $52.1-64.0$ & 0 & 0 & Very Good & & \\
\hline \multicolumn{7}{|c|}{ Science Class 2} \\
\hline Gender & interval & $\mathrm{F}$ & $\%$ & Category & & \\
\hline \multirow{4}{*}{ female } & $16.0-28.0$ & 0 & 0.0 & Not Very Good & 49.52 & 49.00 \\
\hline & $28.1-40.0$ & 0 & 0.0 & Not Good & & \\
\hline & $40.1-52.0$ & 14 & 76.2 & good & & \\
\hline & $52.1-64.0$ & 5 & 23.8 & Very Good & & \\
\hline \multirow{4}{*}{ Male } & $16.0-28.0$ & 0 & 0.0 & Not Very Good & 49.22 & 51.00 \\
\hline & $28.1-40.0$ & 0 & 0.0 & Not Good & & \\
\hline & $40.1-52.0$ & 15 & 83.3 & good & & \\
\hline & $52.1-64.0$ & 3 & 16.7 & Very Good & & \\
\hline \multicolumn{7}{|c|}{ IPA class 3} \\
\hline Gender & Interval & $\mathrm{F}$ & $\%$ & Category & & \\
\hline \multirow{4}{*}{ female } & $16.0-28.0$ & 0 & 0.0 & Not Very Good & 47.31 & 47.00 \\
\hline & $28.1-40.0$ & 0 & 0.0 & Not Good & & \\
\hline & $40.1-52.0$ & 16 & 84.2 & good & & \\
\hline & $52.1-64.0$ & 3 & 15.8 & Very Good & & \\
\hline \multirow{4}{*}{ Male } & $16.0-28.0$ & 0 & 0.0 & Not Very Good & 46.17 & 45.00 \\
\hline & $28.1-40.0$ & 1 & 5.9 & Not Good & & \\
\hline & $40.1-52.0$ & 15 & 88.2 & good & & \\
\hline & $52.1-64.0$ & 1 & 5.9 & Very Good & & \\
\hline
\end{tabular}

Based on table 17, it is known that the study requests of female students in class XII IPA 1 are in the very good category with a percentage of $58.8 \%$ and a mean of 53.23 , a median of 53.00. For class XII IPA 2 women are in the good category with a percentage of 76.2 , an average value of 49.52 and a media value of 49.00. Meanwhile, women in class XII IPA 3 are also in the good category with a percentage of $84.2 \%$, a mean value of 47.31 and a median of 47.00 .

For men in IPA 1 with a percentage of $50.00 \%$ are in the good category with a mean value of 50.42 and a median of 49.50. if seen, men in science class 2 are also in the good category with a percentage of $83.3 \%$. while for men in IPA 3 are in the good category with a percentage gain of $88.2 \%$.

Based on the output obtained, it is known that the science process skills between the female gender and the male gender are almost entirely in the good category. But the majority gender is women who are in the good category. On the indicators observe, measure. Concluding, \& creating a table both the female gender and the male gender are in the good category. But in the indicators of designing experiments \& conducting experiments, the female gender is mostly good while the male gender is not good. In the indicators observed, both women and men were in the good category. This is because observing is a basic indicator that every stu- 
dent must have so that students can develop other science process skills. Based on Mahmudah, (2017) observation skills are skills that designate the five tools found in each student as sight, touch, taste, smell \& hearing. Observation skills embody basic knowledge that can give good results to students, because by seeing students they can relate to continuous experience by allocating the principles they know and can help students to be independent in solving a case and be able to think critically and think creatively (Downing \& Gifford, 1996; Ango, 2002; Darmaji et al., 2019). So that supervising activities are very important for students to master because they can provide more meaningful lessons, because students are guided further to monitor events that occur in their environment. Furthermore, for measurement indicators, female gender and male sex appearance are also included in the good category. Measuring skills also emphasize the basic skills of science process skills, therefore measuring skills must be mastered by students so that students can share other skills. Based on (Mutmainnah et al., 2019) measuring skills are skills used by students in using the senses in the laboratory. The more often students use certain senses, the more skilled students are at taking measurements (Hamdiyati \& Kusnadi, 2007). So that the part in doing practicum students are required to be able to measure the variables available in the experiment. Furthermore, for measurement indicators, female gender and male gender are also included in the good group. Measuring skills also provide basic skills, therefore measuring skills must be mastered by students so that students can share other skills.

The indicator concludes that male \& female are in the good category. Conclusion skills are very crucial to be mastered by students because they are basic skills. Conclusion skills are skills that must be possessed by students because they are skills that indicate the development of students' abilities to be able to draw conclusions and students can find out what the experimental outputs are.
(Nurhasanah, 2016; Hernawati et al., 2018; Jumania et al., 2019).

The skill of forming a table is the intelligence of the part in displaying information in an easy-to-understand way $\&$ in the form of tables or graphs (Mahmudah, 2017). Tablemaking skills are process skills that include actions such as sketching data, writing graphs, \& analyzing data (Hernawati et al., 2018). So that students must master the skills of making tables. Furthermore, on the indicators we experimented \& carried out experiments, various sexes were in the good group while the male sex was in the bad group. Experimental design skills are skills in choosing the senses/materials used and skills in choosing what variables to measure (Maheasy, 2017). Elsewhere, our ability to prepare experiments is a skill that can be improved by doing experiments \& skills such as which are very important in conducting experiments because we can conduct experiments students can choose their senses \& materials and choose what variables to measure (Akani, 2015; Jumania et al., 2019; Ratnasari et al., 2018). Though the ability to conduct experiments makes intelligence has many benefits. This is because the ability to conduct experiments connects the experience gained by students in accordance with the practical activities obtained in accordance with the book. (Ismirianti et al., 2016). Experimental skills are skills that aim to test ideas based on facts, concepts, and principles according to science (Abruscato, 1995; Hernawati et al. , 2018). So that the ability to do experiments is very important for students to master. So based on the output, it was found that the disparity in science process skills was still hidden between female and male sex appearances. The result of this analysis is that science process skills are superior according to female gender than male gender.This is synchronous using statements (Mawarsari et al., 2016; Hamdani, 2017; Yuliskurniawati et al., 2019) which state that female students have better achievement of process skills than male students. The results of this study are also synchronized using research (Zeidan \& Jayosi, 2015; Hamdani, 2017) which states that the 
science process skills possessed by female students are superior to male students. This is because students who prefer practicum activities are female students (Hadi \& Ibnu, 2015). Thus, it was found the effect of gender on students' science process skills. Furthermore, for a critical analysis between female and male gender, there is still a significant disparity. The results of this analysis say that the female gender is superior to the male gender. This research is synchronous using research findings (Cahyono, 2017) Which states that the female gender variance is superior according to the male gender variety. This is because students have intellectual fragments that operate more aggressively in the field of using language functions, as a result, girls are superior to men (Anggoro \& Bambang, 2016; Cahyono, 2017; Hidayanti et al., 2020). On the other hand, Crawford (2005) states that female students have better and more reliable questioning abilities than male students, which means that female students have much better critical intelligence than male students. So that gender has an effect on the critical intelligence of students. It is appropriate to use research (Leach \& Bagus, 2011) which reveals that gender can significantly influence the homogeneity of critical intelligence of students. In addition, because the disparity in science process skills \& critical thinking skills in each child is the disparity in the activities of students in the teaching process through a practical agenda. So that the practicum agenda realizes a very crucial agenda for students to be able to improve their scientific process skills and students' critical thinking skills. Science process skills \& students' critical thinking skills hold a very close association with each other. Students who have high scientific process skills will also have high critical thinking skills. Conversely, if students have low scientific process skills, it will result in low critical thinking skills. So that the low science process skills will make students' learning outcomes low. This is commensurate with the analysis which says that the impact of low science process skills on students is less than optimal student learning outcomes (Kurniawati et al., 2016; Syafriyansyah et al., 2013. Thus, it is necessary to improve science process skills so that the critical intelligence of students is also high. To improve students' science process skills, it is necessary to carry out meaningful learning through exclusive experiences or using practicum-based learning (Ekene, 2011; Murni, 2018; Wahyuni et al., 2020). Practicum is a learning process based on exclusive experience \& a learning process that uses certain skills. The advantage according to practical activities is that students can share scientific ways of thinking. So that practicum is a very crucial activity in improving science process skills \& students' critical thinking skills.

In addition to the different science process skills and critical thinking abilities of male and female students, the interest in learning between male and female genders is also different. Interest in learning is an activity that is carried out by someone in the learning process using feelings of pleasure without being coerced by others. Differences in learning interest of men and women are not too significant. The difference occurs becauseEach student has different abilities and difficulties with different levels.

\section{CONCLUSION}

Based on the research results that have been obtained, it is concluded that there are differences in students' science process skills and critical thinking skills in terms of female and male gender. The results of this study indicate that the female gender has higher scientific process skills and critical thinking skills than the male gender. This is because the female gender has a high curiosity and has a better ability to ask questions than male students. The more students' science process skills increase, the higher students' critical thinking abilities. On the other hand, the lower the students' science process skills, the lower the students' critical thinking skills. so it can be said that science process skills and critical thinking skills have a close relationship. In addition, interest in learning 
between male and female students has a not too significant difference.

The limitation of this research is that it does not examine all aspects (16 indicators) of science process skills. This study only examines 6 aspects of science process skills.

\section{REFERENCES}

Abruscato, J. (1995). Teaching children science: A discovery approach. Allyn \& Bacon.

Agung, A., \& Gede, A. (2014). Educational Research Methodology. Textbook of sEducational Research Methodology. Undiksha.

Akani, O. (2015). Levels of Possession of Science Process Skills by Final Year Students of Colleges of Education in South-Eastern States of Nigeria. Journal of Education and Practice, 6(27), 94101.

Ambross, J., Meiring, L., \& Blignaut, S. (2014). The implementation and development of science process skills in the natural sciences : A case study of teachers' perceptions. 11(3), 459-474. https://doi.org/10.1080/18146627.2014. 934998

Anggoro, \& Bambang, S. (2016). Analysis of Junior High School Students' Perception of Mathematics Learning in terms of Gender Differences and Mathematical Creative Thinking Dispositions. Journal of Mathematics Education, 7(2).

Ango, M. . (2002). Mastery of science process skills and their effective use in the Teaching of Science. N Educology of Science Education in the Nigerian Context, 16(11-30).

Anindyta, P., \& Suwarjo. (2014). The Effect Of Applying Problem-based Learning To Critical Thinking Skill And SelfRegulation. 2(1), 209-222.

Araabi, HF (2017). Schools and skills of critical thinking for urban design. Journal of Urban Design, 4809(September), $1-17$. https://doi.org/10.1080/13574809.2017. 1369874
Ardana, IK, \& Putra, IKA (2017). The Influence Of The Science Technology Science Model Assisted Community Approach. 1, 94-101.

Arieska, PKNH (2018). Selection of Sampling Techniques Based on Relative Efficiency Calculations. Journal of Statistics, 6(2), 166-171.

Arisantiani, N., Putra, M., \& Ganing, N. . (2017). The Effect Of The Childrens Learning In Science (clis) Assisted Environmental Media Learning Model On Science Knowledge Competence. 1, 125-132.

Asrial, A., Syahrial, S., Maison, M., Kurniawan, DA, \& Piyana, SO (2020). Ethnoconstructivism E-Module To Improve Perception, Interest, and Motivation of Students in Class V Elementary School. JPI (Jurnal Pendidikan Indonesia), 9(1), 30. https://doi.org/10.23887/jpiundiksha.v9i1.19222

Astiti, NP., Ardana, I. ., \& Wiarta, I. . (2017). The Influence Of Children Learning In Science Learning Model Based On The Culture Of Investigation On Science Knowledge Competence. Journal of Education Technology, 1(7), 86-93.

Astra, IM, \& Wahidah, RS (2017). Improving Students' Science Process Skills Through Guided Discovery Learning Model Class XI MIPA on Temperature and Heat Material. 3(November), 181-190.

Astuti, YW, \& Mustadi, A. (2014). The Effect of Using Animated Film Media on Narrative Writing Skills for Fifth Grade Elementary School Students. Prima Edukasia Journal, 2(2), 250-262.

Ayuni, IGAPAS, Kusmariyatni, N., \& Japa, IGN (2017). The Effect of Talking Stick Learning Model Assisted by Question Box Media on Science Learning Outcomes for Grade V. Journal of Education Technology, 1(3), 183. https://doi.org/10.23887/jet.v1i3.12503

Cahyono, B. (2017). Analysis of Critical Thinking Skills in Solving Problems in 
terms of Gender Differences. Axiom, $8(1)$,

https://doi.org/10.26877/aks.v8i1.1510

Canziani, B., \& Tullar, WL (2017).

Developing critical thinking through student consulting projects Developing critical thinking through student consulting projects. Journal of Education for Business, 0(0), 1-9. https://doi.org/10.1080/08832323.2017. 1345849

Creswell, JW (2014). Research Design Qualitative, Quantitative, And Mixed Methods Approaches. London: SAGE.

Darmaji, D., Astalini, A., Kurniawan, DA, Ningsi, AP, Romadona, DD, \& Dari, RW (2020). Regression of Science Process Skills On Critical Thinking Skills In Two Junior High Schools In Jambi City. JIPF (Journal of Physics Education), $\quad 5(3), \quad 177$. \https://doi.org/10.26737/jipf.v5i3.1788

Darmaji, D., Kurniawan, DA, \& Irdianti, I. (2019). Physics education students' science process skills. International Journal of Evaluation and Research in Education (IJERE), 8(2), 293. https://doi.org/10.11591/ijere.v8i2.1640 1

Darmaji, D., Kurniawan, DA, Parasdila, H., \& Irdianti, I. (2018). Description of Student Science Process Skills on Thermodynamics Material. Physical Education Scientific Periodic, 6(3), 345. https://doi.org/10.20527/bipf.v6i3.5290

Denny, YR, Utami, IS, Rohanah, S., \& Muliyati, D. (2020). The Development of Blended Learning Model using Edmodo to Train Student Critical Thinking Skills on Impulse-Momentum Topic. 6(1), 113-120.

Downing, J., \& Gifford, V. (1996). An investigation of preservice teachers' science process skills and questioning strategies used during a demonstration science discovery lesson. Journal of Elementary Science Education, 8(1), 64.

Duli, N. (2019). Quantitative Research Methodology: Some Basic Concepts For Thesis Writing \& Data Analysis
With SPSS. Yogyakarta : DEEPUBLISH.

Durmaz, H., \& Mutlu, S. (2016). The effect of an instructional intervention on elementary students' science process skills. The Journal of Educational Research, $\quad 0(0)$, 1-13. https://doi.org/10.1080/00220671.2015. 1118003

Ekene, I. (2011). Effects Of Co-Operative Learning Strategy And Demonstration Method On Acquisition Of Science Process Skills By Chemistry Students Of Different Levels Of Scientific Literacy. Journal of Research and Development, 3(1), 204-212.

Erikson, MG, \& Erikson, M. (2019). Learning outcomes and critical thinking-good intentions in conflict. Studies in Higher Education, 44(12), 2293-2303.

https://doi.org/10.1080/03075079.2018. 1486813

Facione, PA (2000). The Disposition Toward Critical Thinking: Its Character, Measurement, and Relation to Critical Thinking Skill. Informal Logic, 20(1), 61-84.

Ferdiansyah. (2018). Effect Of Communication On Organizational Effectiveness (Case Study on Structural Parties of SMK Letris Indonesia 2 Pamulang). Creative Journal: Marketing, Human Resources and Finance, 6(2), 132-142.

Florencia, M., Mauro, D., Furman, M., Mutlu, A., Ambross, J., Meiring, L., Blignaut, S., Wallace, CS, Coffey, DJ, Wallace, CS, Durmaz, H ., Mutlu, S., Koksal, EA, Berberoglu, G., SoléLlussà, A., Aguilar, D., Ibáñez, M., Mokiwa, HO, Lekhu, MA, ... Obideyi, EI (2014). Status of Integrated Science Instruction in Junior Secondary Schools of China: An exploratory study. Journal of Science Teacher Education, 00(1), 21-27.

https://doi.org/10.1080/10288457.2014. 942961

Ganing, NN (2019). The Effect Of Visual 
Media Assistance Of Picture And Picture Learning Model On Indonesian Skills. 3, 278-285.

Giancarlo, CA, \& Facione., PA (2001). A Look Across Four Years at the Disposition Toward Critical Thinking Disposition among Undergraduate Students. The Journal of General Education, 50(1), 29-55.

Groeneveld, S., Tummers, L., Bronkhorst, B., Ashikali, T., \& van Thiel, S. (2015). Quantitative methods in public administration: Their use and development through time. International Public Management Journal, 18(1), 6186.

https://doi.org/10.1080/10967494.2014. 972484

Hadi, MS, \& Ibnu, S. (2015). The Influence of Subject Specialization Groups and Gender on Learning Outcomes and Scientific Process Skills of Students on Reaction Rate Material. 3(1), 31-41.

Halpern, DF (2003). Thought and Knowledge: An Introduction to Critical Thinking.

Hamdani. (2017). Description of Science Process Skills for Prospective Physics Teacher Students. Journal of Mathematics and Science Education, 8, 43-51.

Hamdiyati, Y., \& Kusnadi. (2007). Profile of Students' Science Process Skills Through Scientific Work-Based Learning in Microbiology Courses. Journal of Mathematics and Natural Sciences Teaching, 10(2), 36-42.

Handika, I., \& Wangid, MN (2013). The Effect of Problem-Based Learning on Mastery of Concepts and Science Process Skills for Class V Students. Prima Edukasia Journal, 1(1), 85. https://doi.org/10.21831/jpe.v1i1.2320

Haniah, AR, Aman, A., \& Setiawan, R. (2020). Integration of strengthening of character education and higher order thinking skills in history learning. Journal of Education and Learning (EduLearn), 14(2), 183-190. https://doi.org/10.11591/edulearn.v14i2.
15010

Harahap, M., Sulardiono, B., \& Suprapto, D. (2018). Analysis of Rivet Sea Cucumber (HOLthuria Autra) Maturity Levels in Menjangan Kecil Waters, Karimunjawa. Journal of Maquares, 7(3), 263-269. http://awsassets.wwfnz.panda.org/down loads/earth_summit_2012_v3.pdf\%0Ah ttp://hdl.handle.net/10239/131\%0Ahttps ://www.uam.es/gruposinv/meva/publica ciones jesus/capitulos_espanyol_jesus 12005_motivacion para el aprendizaje Perspectiva alumnos.pdf\%0Ahttps://ww Haryono. (2006). Learning Model Based on Science Process Skills Improvement. Journal of Basic Education, 7(1), 1-13.

Hernawati, D., Amin, M., Irawati, MH, Indriwati, SE, \& Omar, N. (2018). The effectiveness of scientific approach using encyclopedia as learning materials in improving students' science process skills in science. Indonesian Journal of Science Education, 7(3), 266-272.

https://doi.org/10.15294/jpii.v7i3.14459

Hidayanti, R., Alimuddin, \& Syahri, A. . (2020). University of Muhammadiyah Makassar 1, 3 , Makassar State University 2 E-mail: SIGMA Journal, 12(1), 71-80.

Ismirianti, U. ., Dewi, N. ., \& Taufiq, M. (2016). The Effect of Guided Discovery Practicum Instructions on the Skills of Conducting Experiments and Communicating Results on the Theme of Pressure. USEJ - Unnes Science Education Journal, 5(2), 1261-1271. https://doi.org/10.15294/usej.v5i2.1314 5

Israel, M., Wherfel, QM, Shehab, S., Ramos, EA, Adam, M., \& Reese, GC (2016). Assessing collaborative computing: development of the CollaborativeComputing Observation Instrument (CCOI). Computer Science Education, 3408, 1-26. https://doi.org/10.1080/08993408.2016. 1231784

Istiyono, E. (2020). Developing Instrument 
of Essay Test to Measure the ProblemSolving Skill in Physics. Indonesian Journal of Physical Education, 16(2), $72-82$.

https://doi.org/10.15294/jpfi.v16i2.2424 9

Johanson, J. (2010). Cultivating critical thinking : An interview with Stephen Brookfield. Journal of Developmental Education, 33(3), 26-30.

Jumania, Irawan, B., \& Putri, A. . (2019). Profile of Students' Science Process Skills in Science Learning Class VIII at SMP Negeri 8 Tanjungpinang. Biological Pedagogy, 3(1), 8-13. https://doi.org/10.31629/ph.v3i1.1340

Karelina, A., \& Etkina, E. (2007). acting like a physicst : student approach study to experimental design. Physics Education Research, 94(5), 810-824.

Kurniawan, DA, Astalini, A., Darmaji, D., \& Melsayanti, R. (2019). Students' attitude towards natural sciences. International Journal of Evaluation and Research in Education, 8(3), 455-460. https://doi.org/10.11591/ijere.v8i3.1639 5

Kurniawan, DA, Kurniawan, W., Anwar, K., \& Lumbantoruan, A. (2019). Students perceptions of electronic 's module in physics practicum. 13(2), 288-294. https://doi.org/10.11591/edulearn.v13i2. 13005

Kurniawati, D., Masykuri, M., \& Saputro, S. (2016). Application of the Guided Inquiry Learning Model Equipped with Worksheets to Improve Science Process Skills and Learning Achievement on the Basic Law of Chemistry for Class X Mia 4 Sma N 1 Karanganyar Academic Year 2014/2015. Sebelas Maret University Journal of Chemical Education, 5(1), 88-95.

Leach, BT and, \& Good, DW (2011). Critical Thinking Skills as Related to University Students' Gender and Academic Discipline, International Journal of Humanities and Social Science,. International Journal of Humanities and Social Science, 1(21).
Lestari, HD (2020). Development of Science E-Modules with Online Tests to Improve Learning Outcomes. 4, 73-79.

Loes, CN, \& Pascarella, ET (2017). Collaborative Learning and Critical Thinking : Testing the Link Collaborative Learning and Critical Thinking : Testing the Link. The Journal of Higher Education, 88(5), 726-753.

https://doi.org/10.1080/00221546.2017. 1291257

Made, N., Lestari, D., Suniasih, NW, \& Darsana, IW (2017). The Effect Of Snowball Throwing Learning Model Based On Children'S Song On Knowledge Competence Of Pkn. 1, 163-168.

Maheasy, L. (2017). The Importance of a Process Skills Approach in Science Learning in Madrasahs. ELEMENTARY: Islamic Teacher Journal, $\quad 4(1)$. https://doi.org/10.21043/elementary.v4i 1.2047

Maiyena, S., \& Haris, V. (2017). Practicality of Video Tutorials in Experimental Physics Courses to Improve Students' Science Process Skills. Al-Biruni Scientific Journal of Physical Education, $\quad 6(1), \quad 75-83$. https://doi.org/10.24042/jpifalbiruni.v6i 1.647

Malik, A., Novita, Y., \& Yeti, A. (2019). Enhancing Critical Thinking Skills of Students Related to Temperature and Heat Topics Through Problem SolvingLaboratory Model. April.

Malik, A., Oktaviani, V., \& Handayani, W. (2017). Application of the Process Oriented Guided Inquiry Learning (POGIL) Model to Improve Students' Critical Thinking Skills. 3(September), 127-136.

Mariana, S., \& Zubaida, E. (2015). Prima Edukasia Journal. The Effect Of The Use Of The Hands Up Media On The Storying Skills Of ThE Vth Grade Elementary School Students in Cluster 4, Bantul District, 3, 166-176. 
Marquezin, MC., Pedroni-pereira, A., Santos, D., Rosar, JV, Barbosa, TS, \& Castelo, PM (2016). Descriptive analysis of the masticatory and salivary functions and gustatory sensitivity in healthy children. 6357(June). https://doi.org/10.1080/00016357.2016. 1191085

Mawarsari, O., Subali, B., \& Wibowo, Y. (2016). Creativity Science Process Skills Aspects of Elementary School Students' Life Based on Gender Aspects. Journal of Biology Education, 5(3).

McPeck, J.E. (1990). Critical Thinking and Subject Specificity: A Reply to Ennis. Educational Researcher, 19, 10-12.

Mokiwa, HO (2014). Exploring the Teaching of Physical Science through Inquiry. International Journal of Educational Sciences, $\quad 7(1)$, 21-27. https://doi.org/10.1080/09751122.2014. 11890166

Pure. (2018). Profile Of Students And Process Science Skills. 6(1), 118-129.

Mutlu, A. (2020). International and Multidisciplinary Perspectives Evaluation of students' scientific process skills through reflective worksheets in the inquiry-based learning environments. Reflective Practice, $\quad 00(00), \quad 1-16$. https://doi.org/10.1080/14623943.2020. 1736999

Mutmainnah, SN, Padmawati, K., Puspitasari, N., \& Prayitno, BA (2019). Profile of Science Process Skills (Kps) Biology Education Students Judging from Academic Ability Profile of Science Process Skills in Biology Education (Case Study At a University in Surakarta). Biology Didactics: Journal of Biological Education Research, 3, 49-56.

Nasution, SW. (2018). Application Of The Guided Inquiry Model In Improving Critical Thinking Ability. 3(1), 1-5.

Noughabi, HA (2016). Efficiency of ranked set sampling in tests for normality. Journal of Statistical Computation and
Simulation, $\quad 0(0), \quad 1-10$. https://doi.org/10.1080/00949655.2016. 1238090

Nurhasanah. (2016). The Use of Students' Science Process Skills Test (KPS) in Learning the Concept of Heat with the Guided Inquiry Model. Thesis FITK, UIN Syarif Hidayatullah Jakarta.

Pithers, R., \& Soden, R. (2000). Critical Thinking in Education; A Review. Educational Research, 42(3), 237-249. https://doi.org/doi:10. 1080/001318800440579.

Quintela-del-río, A., \& Francisco-fernández, M. (2016). Excel Templates : A Helpful Tool for Teaching Statistics Excel Templates : A Helpful Tool for Teaching Statistics and. 1305, 1-23. https://doi.org/10.1080/00031305.2016. 1186115

Rahmawati, R., \& Mahmudi, A. (2014). The Effectiveness of STAD and TAI Cooperative Learning in terms of Students' Mathematics Learning Activities and Achievements. Prima Edukasia Journal, 2(1), 102-115.

Ratnasari, D., Sukarmin, S., Suparmi, S., \& Harjunowibowo, D. (2018). Analysis of science process skills of summative test items in physics of grade $X$ in Surakarta. Indonesian Journal of Science Education, 7(1), 41-47. https://doi.org/10.15294/jpii.v7i1.10439

Rediarta, IW, Sudarma, IK, \& Murda, In (2014). The Influence Of The Two Stay Two Stray Cooperative Model On Ipa Learning Outcomes, Ganesha University of Education. Journal of the PGSD Pulpit Ganesha University of Education, 2(1).

Ritdamaya, D., Suhandi, A., Bachelor, P., Education, J., Upi, F., \& Setiabudhi, J. (2016). Construction of Critical Thinking Skills Test Instruments Related to Temperature and Heat Materials. 2, 87-96.

Rokhmah, A., Sunarno, W., \& Masykuri, M. (2017). Science Literacy Indicators In Optical Instruments Of Highschool Physics Textbooks Chapter. 
13(January),

$19-24$. https://doi.org/10.15294/jpfi.v13i1.8391

Setia, MO, Susanti, N., \& Kurniawan, W. (2017). Adobe Flash CS 6. 02(02), 4257. https://onlinejournal.unja.ac.id/EDP/article/view/396 3

Shaw, A., Liu, OL, Gu, L., Kardonova, E., Chirikov, I., Li, G., Hu, S., Yu, N., Ma, L., Guo, F., Su , Q., Shi, J., \& Loyalka, P. (2019). Studies in Higher Education Thinking critically about critical thinking : validating the Russian HEIighten @ critical thinking assessment Thinking critically about critical thinking : validating the Russian. Studies in Higher Education, 5079.

https://doi.org/10.1080/03075079.2019. 1672640

Sholihah, TM, \& Lastariwati, B. (2020). Problem based learning to increase competence of critical thinking and problem solving. Journal of Education and Learning (EduLearn), 14(1), 148154.

https://doi.org/10.11591/edulearn.v14i1. 13772

Stupnisky, R. ., RD Renaud, Daniels, M., Haynes, TL, \& Perry., and RP (2008). The Interrelation of First-Year College Students' Critical Thinking Disposition, Perceived Academic Control and Academic Achievement. Research in Higher Education, 46(9), 513-530. https://doi.org/doi:10.1007/s11162-0089093-8.

Sukerni, P. (2014). Development of Science Education Textbooks for Class IV Semester I SD No. 4 Kaliuntu With Dick and Carey Model. JPI (Jurnal Pendidikan Indonesia), 3(1), 386-396. https://doi.org/10.23887/jpiundiksha.v3i1.2920

Syafriyansyah, Suyanto, E., \& Nyeneng, ID . (2013). The effect of science process skills (KPS) on students' physics learning outcomes through the experimental method with a guided inquiry approach.
Taqwa, M, R, A., Faizah, R and Rivaldo, L. (2019). Development of Poe-Based Student Worksheets and Students' Critical Thinking Ability on the Topic of Static Fluids. Journal of EduPhysics, 4(1), 6-14.

Wahyudi, Verawati, NNSP, Ayub, S., \& Prayogi, S. (2019). Conceptual Framework of Inquiry-Creative-Process Learning Model to Promote Critical Thinking Skills of Physics Prospective Teachers. 15(January), 5-13. https://doi.org/10.15294/jpfi.v15i1.1069 3

Wahyuni, S., Suhendar, S., \& Setiono, S. (2020). Profile of Science Process Skills for Class $\mathrm{X}$ Senior High School Students. Journal of Pelita Pendidikan, $8(1)$, 41-45. https://doi.org/10.24114/jpp.v8i1.17246

Wallace, CS, \& Coffey, D. . (2019). Investigating Elementary Preservice Teachers' Designs for Integrated Science / Literacy Instruction Highlighting Similar Cognitive Processes. Journal of Science Teacher Education, $\quad 0(0), \quad 1-21$. https://doi.org/10.1080/1046560X.2019. 1587569

Watson, G., \& Glaser, E. . (2008). WatsonGlaser Critical Thinking Appraisal. TX: Pearson Education, Inc.

Wibisono, D. (2013). Business Research. Main Library Gramedia.

Wyatt, JE, Velamakuri, NSC, \& Myers, OJ (2017). Statistical analysis conducted during the study on the impact of toolchip contact time on the shear angle in orthogonal machining. Advances in Materials and Processing Technologies, 0698,

$1-19$.

https://doi.org/10.1080/2374068X.2017. 1420289

Yanti, FA, Kuswanto, H., Habibi, H., \& Kinasih, A. (2020). Development of Analogy-Based Material Physics Module to Provide Analogy Ability of Physics Teachers Candidates. Indonesian Journal of Physical Education, $\quad 16(1), \quad 34-40$. 
https://doi.org/10.15294/jpfi.v16i1.9122 Yuliskurniawati, ID, Noviyanti, NI， \& Mukti, WR (2019). Science Process Skills Based on Genders of High School Students Science Process Skills Based on Genders of High School Students. https://doi.org/10.1088/17426596/1241/1/012055
Yusuf, F. (2009). Validity and Reliability Test of Quantitative Research Instruments. Scientific Journal of Education, 7(1), 17-23.

Zeidan, A. ., \& Jayosi, M. . (2015). Attitudes toward Science among Palestinian Secondary School Students. World Journal of Education, 5(1), 13-24. 